opinion that the defender would not have been entitled to succeed if the assignation had not been rendered effectual because of her own failure to complete it by intimation, or even because of non-fulfilment by the bankrupt of an ordinary personal obligation. But he thought the case was different where there were allegations of breach of duty and frand, and that a trustee in bankruptcy was not entitled to enlarge the estate for distribution by adopting a fraud on the part of the bankrupt. He accordingly allowed the defender before answer a proof of her averments of breach of duty and fraud. The action was shortly afterwards settled.

The case is only of importance as showing that there may be circumstances in which an unintimated assignation may be held to be effectual as in a question with the person who had a duty to intimate. It does not directly affect the question of the position of the debtor in the obligation assigned, who is only bound to make payment to an assignee, of whose right he has notice. But if the debtor is faced with a claim such as was made to the Bank by Mrs. Paul the case shows he would not be in safety to pay elsewhere,-I am, etc., JOHN L. WARK.

Edindurgh, 27th November 1912.

\title{
Combined Endowment Policy and Policy dnder the Married Womens' Policies of Assurance Act.
}

SiR,-The case of Chrystal's Trustee v. Chrystal, reported 1912 S.C. 1003 ; 49 S.L.R. 726 ; 1912, I S.L.T. 500, appears to me to be of special interest to the Faculty.

This was a special case raised to determine the right to the proceeds of two insurance policies on the life of David Chrystal effected in 1894 with the Equitable Life Assurance Society of the United States. By the terms of each policy the Society agreed to make one or other of the following payments to the assured, viz., (1) a payment of $£ 1136$ as at 18th August, 1914, the date of maturity of the policies, with surplus then to be apportioned; (2) the surplus in cash and $£ 1000$ at the end of ten years from said date or at prior death, paying interest at five per cent. per annum on the sum of the annual premiums paid; (3) conversion of the surplus into an annuity to increase the annual income on the policy and payment of $£ 1000$ after ten years or at prior death with interest as above ; $(4)$ conversion of the policy and surplus into an annuity for life. The policies further provided that, in the event of the death of the said David Chrystal before the expiration of twenty years from the date thereof and while the policies were in force, the Society would pay $£ 1000$ to his wife, Eliza Angusta Smith or Chrystal, if living, and if not, then to the said David Chrystal's executors, administrators or assigns.

Attached to each policy was a list of privileges guaranteed to the assured. One of these was a provision that if after having been in force for three years the policty should lapse from non-payment of premium it should have a surrender value in non-participating paid-up assurance for as many twentieths of the sum assured as annual premiums paid, provided that surrender were made within six months after default in payment of the premium. This paid-up policy would mature at the same time as the original policy or might be extended for a further period of ten years or until prior death. If thus extended the paid-up policy would be entitled annually to as many twentieth parts of the income guaranteed under the orıginal policy as annual premiums had been paid.

David Chrystal died on 19th January 1911, insolvent, and his estates were afterwards sequestrated. The proceeds of the policies were claimed by his trustee in bankruptcy and also by his widow. The special case 
stated that the widow gave no price or consideration to her husband in respect of his effecting and keeping up these policies. She did not accept them as in lieu of any of her rights under her marriage contract or as in implement of any of her husband's obligations under that contract. The premiums were paid wholly by him, and he died before the expiration of twenty years from the date of the policies. It appeared from a minute put in by the parties at the request of the Court that in the event of surrender of the policies the Society would endorse them as follows: "Inasmuch as the premium due has not been paid upon the within policy, it is hereby agreed and declared that, in accordance with the wish of the assurant, the said policy has become a paid-up policy for $£$ sterling, without profits, requiring no further payments except for extraordinary privileges. The pard-up policy will not participate in the tontine or any other dividend, will be known under No. , and in favour of the same beneficiaries as before. The conditions of the said policy, except as herein modified remain as before."

The First Division of the Court (The Lord President, Lords Kinnear, Johnston, and Mackenzie) found that the widow was entitled to the proceeds of the policies. LorD JoHnston, who gave the leading opinion, remarked that the difficulty in the case arose from the fact that the policies were a combination of an ordinary Endowment Assurance and a "Married Women's Policy of Assurance." As regards the primary interest of the assured they were twenty-year endowment policies, and after the expiry of the endowment period the assured alone was entitled to the benefits undem the policies. But within the twenty years the polıcies were a provision for the wife of the assured. He pointed out that in the usual married women's policy the husband conferred a right on his wife contingent on his predeceasing her, while these policies conferred a right on the wife contingent on a double event, viz., the husband (1) predeceasing and (2) dying within the twenty years. But in his opinion the policies, notwithstanding this double contingency, came under the protection of the Married Women's Policies of Assurance (Scotland) Act, 1880. They were effected by a married man on bis own hfe and expressed on the face of them to be for the benefit of his wife. The statute did not restrict the benefit of the wife to any specified interest in the policy, or say that her interest must be absolute and void of contingency so as to leave nothing in the husband. It was recognised that her interest might be clogged with the contingency of her surviving her husband, and that should she not do so, his radical right would result. On the same principle the wife's benefit might depend upon the double contingency arising in this case, and yet the policies be for the benefit of the wife in the sense of the Act. He could not read the statute as requiring that the policies must be in favour of the wife unconditionally to admit of them, "together with all benefit thereof," being deemed a trust for the benefit of the wife. He read the enactment as providing that the policies and all benefit thereof shall be deemed a trust for the benefit of the wife for her interest as that interest is defined or expressed in the policies.

LORD MACKENZIE's view of the provisions of the policies was that the husband was desirous by contributing out of his annual savings to have at his command at the maturity of the policies a capital sum of money. He was also desirous of safeguarding the interests of his wife during the period when these savings were being made. The same considerations would apply if a person entitled to succeed to an estate insured his life for the benefit of his wife to provide for the contingency of his not succeeding to the estate. The two parts of the policies were and must be kept separate. Nothing that the husband could do so long as the annual premiums continued to be pard could diminish the benefit secured by the terms of the policies to his wife during the currency of the twenty years. The condition as to surrender appeared to him to cause a possible difficulty, because if its 
true meaning was that the husband could at any time during the twenty years make available as a fund of credit for his own behoof the amount of the premiums then pard up this would put an instrument in his hands which might enable him to defeat the wife's interest. The minute lodged by the parties removed this difficulty, because it made it clear that the paidup assurance substituted for the original policy was to be in favour of the same beneficiaries as before. The nature of the right vested in the wife would remain the same as before. Its extent only would be affected. The husband had obtained loans on the policies but the indefeasible nature of the wife's right was recognised by the fact that the assignments in security which the Society took were granted by her as well as by her husband. The policies were effected by a married man on his own life and were expressed on the face of them to be for the benefit of his wife. They therefore, in terms of the second section of the Act, were to be deemed a trust for the benefit of the wife for her separate estate. Immediately on their being effected they vested in the husband in trust for the purpose so expressed, and were not subject to his control, nor did they form part of his estate, nor were they liable to the diligence of his creditors, nor revocable as a donation nor reducible on any ground of excess or insolvency. There was no definition or limitation in the Act as to the form in which a policy was to be expressed. The fact that in certain circumstances there is a destination to the husband's executors, administrators or assigns will not prevent the statutory consequences of the policy receiving effect. As matters stood during the whole of the twenty years until the policies matured they were held, by virtue of the Act, for the wife absolutely. It appeared to his Lordship that there must be in all such cases the possibility of a resulting benefit in favour of the husband. It was so in the case of Schumann v. The Scottrsh Widows' Fund Society, $13 R$. 678., and also in two cases under the English Act (Holt v. Everall, 1876, 2 Ch. D. 266, and Seyton v. Satterthwaite, 1887, $34 C h$. D. 511.) In these cases it was held that the possibility of a resulting trust in favour of the husband's representatives did not exclude the operation of the Act.

LORD KInNeAR observed that the conclusive consideration to his mind was that, in the event which had happened, the policies gave the whole benefit of the insurance money to the wife of the insured, and that in terms fell within the second section of the Act. The contingent right of the husband never became absolute, and was completely and finally determined by his death. The result was to leave these policies for the benefit of the wife alone. The Act applied, and as it expressly enacts that the assurance shall not be revocable as a donation inter vivum et uxorem the insurance money could not be paid to the husband's creditors.

The Lord President intimated that he had had difficulty. At common law the fund in dispute would undoubtedly belong to the husband's creditors, and it was the Act alone which effectuated the other result. What had struck him at first was that the policies were certainly prima facie not for the benefit of the wife, but for the benefit of the husband himself, because the first clause provided that if he lived to a certain age he would get a sum of money, and the provision in favour of the wife was only put in to meet the case of his not living to that age. But he felt that the Act was an enabling statute, and that the class of insurance here disclosed was a sensible one. It provided for the wife, if the husband was taken away by an early death, and on the other hand, if he lived long enough it provided him with a considerable sum of money out of which he could make provision for her after his death. His Lordship did not therefore feel sufficient confidence in the view that first struck him to intimate a formal dissent. - Yours, etc., JOHN L. WARK.

Eininurgh, 9th December 1912. 